\title{
シリアルリンク機構のための仮想重力機構の解析*
}

山田 泰之*1,*2, 森田 寿郎 ${ }^{* 3}$

\section{A Fundamental Kinematic Analysis of Virtual Gravity Controller for Serial Link Mechanism}

\author{
Yasuyuki YAMADA*1 and Toshio MORITA \\ ${ }^{* 1}$ Keio University. Graduate School of Science and Technology \\ 3-14-1 Hiyoshi, Kohoku-ku, Yokohama-shi, Kanagawa, 223-8522 Japan
}

In this paper, we propose a passive gravity vector control mechanism, which named "Mechanical Gravity Generator (MGG)." From development and geometry calculation of a link model with the MGG, it is clarified that our device has three advantages described below in comparison with conventional passive gravity compensation mechanisms and other handling mechanisms. (1) In all directions, it allows the passive stabilization of the links by setting parameters of MGG. (2) MGG increases the payload than conventional passive gravity compensation mechanisms when the link position is under the equilibrium positions. (3) The equilibrium positions of serial links with MGG can be designed independently for each link. In conclusion, the novel device enabled to get high power and easy posture control by the effect of generated virtual gravity.

Key Words : Balancing, Material Handling Equipment, Mechanism, Geometry Calculation

\section{1. 緒言}

物資運搬作業，土木作業，組み付け作業などでは，垂直平面内で回動する作動リンクを備えた機器が広く利用 されている．このような機構において，高応答性や高出力を得ようとすると，アクチュエータを含む装置全体が 急激に大型化・重量化して，設計上の悪循環に陥る．この問題の解決には，回転対偶に生じる自重トルクを機構 的にゼロに近似させるための機械的な自重補償が有効であるとされている(1) (5). この機構は外部からのエネルギ 一供給なしに，作動リンクの見かけ上の重量をゼロにすることを目指すものである．カウンタウエイトを用いる 場合 ${ }^{(1)}$, 完全な自重補償を実現できるが, 装置総重量・慣性モーメントが倍増するため, リンクの動作速度, 加 速度の低下や, 装置全体の飛躍的な重量増加に留意する必要がある. このウエイトによる重量増加を伴わない自

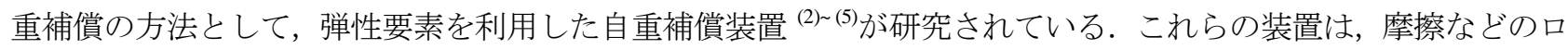
スがなくても近似的な自重補償しか行えないものや(2), 設計理論上は完全な自重補償が可能であっても，実設計 上無視できない誤差を含む場合がほとんどであった ${ }^{(3)}$.

そこで著者らは更なるペイロードの向上を目指し，実設計上においても摩擦のロス以外の誤差をほとんど発生 させない Compression spring Gravity Canceller : CGC ${ }^{(5)}$ を開発した。しかし，発生した補償トルクが自重トルクと完 全に一致していない場合 ${ }^{(2)(3)}$ は, 作動リンクの運動方程式をかえって複雑にしてしまい高度な制御則が必要となっ たり, 完全に自重トルクを相殺している場合 ${ }^{(5)}$ は, 機構的な安定点が存在していなため, 特定の平衡点近傍におけ る線形近似などを利用した制御則が適用しにくくなるなどの制御面での問題は解決されていない．この制御面で の問題は，一般的なマニピュレータにおいても生じるものである. 例えば, 空動マニピュレータでは, 空気圧信 号のむだ時間による発振，非線形摩擦の影響による位置決め誤差が問題となる．そこで，ニューラルネットワー クを用いた補償器によって，これらの非線形系の動特性を安定化させるなどの工夫がなされている(6).

また，位置と力の制御を行うために，八イブリット制御法が広く使われているが，このような場合，逆動力学

* 原稿受付 2011 年 6 月 28 日

*1 正員, 慶應義塾大学大学院理工学研究科（†223-8522 神奈川県横浜市港北区日吉 3-14-1）

${ }^{* 2}$ 日本学術振興会

*3 正員, 慶應義塾大学理工学部

E-mail: 156@z6.keio.jp 


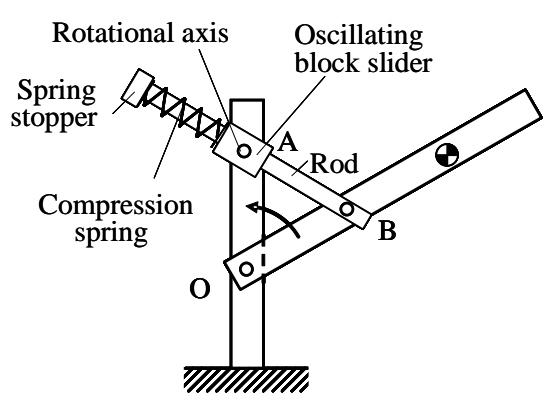

Fig. 1 CGC

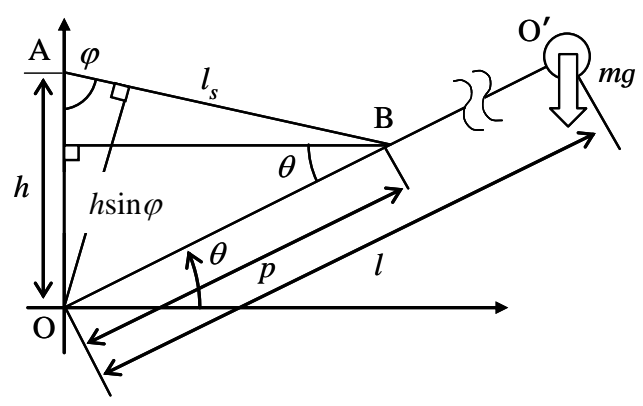

Fig. 2 Configuration of CGC

計算や摩擦などのパラメータ変動の補償には多大な計算が必要となり, 実時間内での制御が難しい場合などがあ る.これを改善するため, 例えば, 力の偏差を速度べクトルに変換することにより, 逆動力学を必要としない位 置と力の制御などが提案されている(7). このように個々のハードウエアに対して, 目的に応じた制御則が提案さ れているが，ハードとソフトの双方から統一的にマニピュレータの制御を行う方法は検討されない傾向にあると 考えられる，一方で，作動リンクが鉛直下向き近傍で制御する場合，一様に働く重力が作動リンクを平衡させる ように㗢くため，線形近似などによる運動方程式の簡単化などが可能となる．もし，任意の方向に仮想的な重力 を働かせることができたら，いかなる方向においても作業リンクの姿勢や位置，その姿勢にいたる力や速度を同 様の制御則で設定することが期待できる.

本研究では，作動リンクが行う目的の作業に対して，その基準姿勢となる方向に作業リンクを平衡させるよう に働く仮想的な重力を機構によって任意に付加することで, 自重補償による高応答性や高出力に加えて, 新たに 制御則の簡単化という性質を持たせることを目的とした．本報告では，考案した機構がばね定数と基部傾斜角度 の 2 つのパラメータの調整によって，任意の方向と大きさの仮想的な重力を構成できることを示すとともに，出 力特性と多連結した場合の姿勢変化についても解析を行い, その効果を明らかにした.

\section{2. 自重補償}

提案する仮想重力機構は, 基本原理として完全な機械的な自重補償を実現している CGC(図 1)を利用する. 図 1 に示すように, 摇動スライダ機構と支柱は点 Aの回転軸受で接続されている.ロッドの一端にはばね受けがあり， 他端は点 B で作動リンクに回転軸受で接続されている．圧縮ばねは，ばね受けと摇動スライダ機構下端に挟まれ る形で配置されている．ロッドが作動リンクの姿勢変化に従ってスライドし，ばね受けと摇動スライダ機構の間 隔が伸縮し，圧縮ばねが変位することでリンクの自重が補償される．本章では，仮想重力機構の原理を説明する ために，このCGC の基本原理を説明する. CGC の原理モデルを図 2 に示寸．作動リンクの回転軸を点 O, 作動 リンクの先端側の端点を点 $\mathrm{O}^{\prime}$ とし，点 $\mathrm{O}$ から直上に $h$ の点を点 $\mathrm{A}$ ，点 $\mathrm{O}$ から作動リンクに沿って $p$ の点を点 $\mathrm{B}$ とする. CGC の圧縮ばねのばね定数を $k_{\mathrm{CGC}}$ として, 自然長からの変位量が $l_{s}$ と等しくなるように調整する。この とき作動リンク重心が点 $\mathrm{O}$ から作動リンクに沿って距離 $l$ で, 質量を $m$, 重力加速度を $g$ とすると, 点 $\mathrm{O}$ まわ りに発生するばねカトルク $\tau_{\mathrm{L}}$ は,

$$
\tau_{\mathrm{L}}=k_{\mathrm{CGC}} l_{s} h \sin \varphi
$$

となる．また，図 2 の幾何条件から

$$
l_{s} \sin \varphi=p \cos \theta
$$

の関係が導かれる. 次に式(1), 式(2)より $l_{\mathrm{s}} \sin \phi$ を消去すると,

$$
\tau_{\mathrm{L}}=k_{\mathrm{CGC}} p h \cos \theta
$$

と $\tau_{\mathrm{L}}$ を $\cos \theta$ の関数として表せる. 一方で, 作動リンクの自重トルク $\tau_{\mathrm{A}}$ は 


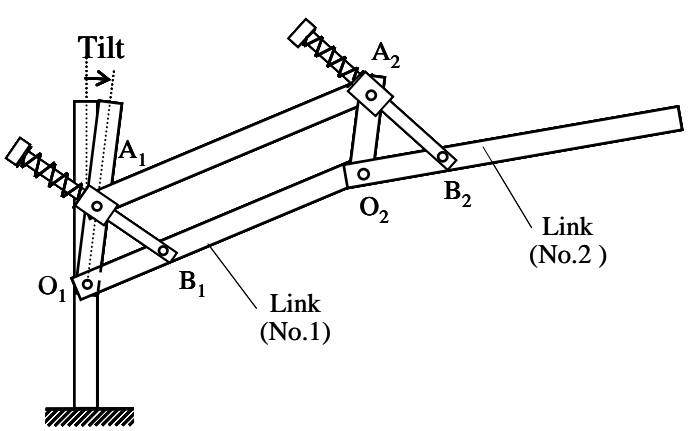

Fig. 3 Two DOF MGG

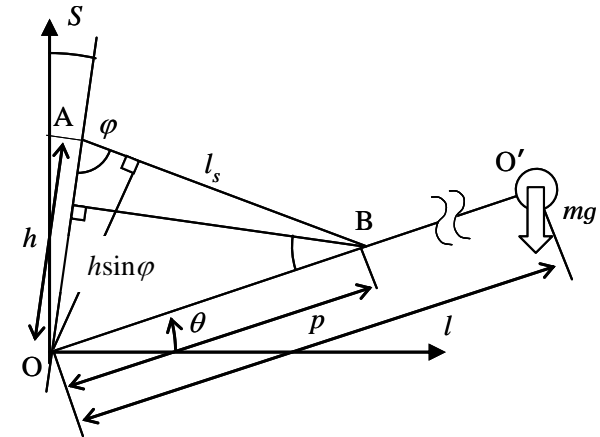

Fig. 4 Configuration of MGG

$$
\tau_{\mathrm{A}}=m g l \cos \theta
$$

となる．ここで，圧縮ばねのばね定数 $k_{\mathrm{CGC}}$ を式(5)のように設定する.

$$
k_{\mathrm{CGC}}=\frac{m g l}{p h}
$$

すると, 点 $\mathrm{O}$ まわりのトルク $\tau_{\mathrm{grav}}$ は式(6)のようにと表せ, 作動リンクの角度 $\theta$ によらず自重補償が可能となる.

$$
\begin{aligned}
\tau_{\text {grav }} & =\tau_{\mathrm{L}}-\tau_{\mathrm{A}} \\
& =k_{\mathrm{CGC}} p h \cos \theta-m g l \cos \theta \\
& =0
\end{aligned}
$$

\section{3. 仮想重力機構}

\section{$3 \cdot 1$ 概要}

提案する仮想重力機構(Mechanical Gravity Generator : MGG)は, 図 3 のように, CGC などの完全な機械的な自重 補償を実現できる機構において, 各作動リンクの自重補償の倍率と基部の傾斜角度を調整可能とした多連結シリ アルリンク機構である．提案する MGG は，CGCを備えた作動リンクが直列に連結されており，さらに先端の作 動リンクの角度変化による力のモーメントが基部に近い作動リンクの姿勢変化に影響しないように平行リンク機 構で構成されている. 図 3 の $\mathrm{MGG}$ の基部関節は, 第 1 作動リンクの回転中心 $\mathrm{O}_{1}$ を回転の中心として任意に傾斜 できる構造となっている. この基部の傾斜角度と, 第 1 作動リンクの自重補償用ばねのばね定数, 第 2 作動リン クのばね定数を適宜調整することで，ばね力ベクトルと重力ベクトルの合成ベクトルの方に作業リンク姿勢を 平衡させることが可能である. なお，複数本の理想ばね(自然長のないばね)を用いた自重補償機構は，1 本の理想 ばねを用いた機構に合成できる ${ }^{(8)}$ ，そのため，今回は 1 本の理想ばねを用いた CGC を利用して MGG を提案する が，この機構解析により, 複数本のばねで構成した場合の仮想重力機構も同様に扱うことができる.

\section{$3 \cdot 2$ 原理}

図 3 のように MGG の第 1 作動リンクは，平行リンクを構成しているため，第 2 作動リンクの姿勢変化に伴う モーメント変化の影響を受けない，そのため，垂直方向に対する姿勢変化についてはそれぞれの作動リンクを独 立して考えることができる. そこで，図 4 に示した MGGの単リンクのみの原理モデルを解析対象とした．この モデルは, 図 2 の CGC と同様に質量 $m$ の作動リンク重心が点 $\mathrm{O}$ から作動リンクに沿って $l$ の点 $\mathrm{O}^{\prime}$ にあり, 点 $\mathrm{A}$, 点 $\mathrm{B}$ 間にばね定数 $k_{\mathrm{MGG}}$ のばねが, 自然長からの伸び量が $l_{s}$ と等しくなるように調整して配置されている.ここで, 作動リンクのばねが自重補償用のばねの何倍にあたるかを, 自重補償倍率 $R\left(\right.$ ただし $\left.R=k_{\mathrm{MGG}} / k_{\mathrm{CGC}}\right)$ とし, 基部の 傾きを鉛直方向から右向きにとった基部傾斜角度 $S(0<S<\pi)$ を定義し，作動リンクパラメータを $(R, S)$ と表記すれ ば，作動リンクが平衡する姿勢は以下のように導出できる。ばねが点 $\mathrm{O}$ まわりに発生させるトルク $\tau_{\mathrm{L}}$ は, 


$$
\tau_{\mathrm{L}}=k_{\mathrm{MGG}} l_{s} h \sin \varphi
$$

となる。また，図 4 に示した MGG の原理モデルの幾何条件から,

$$
l_{s} \sin \varphi=p \cos (\theta+S)
$$

の関係が導かれる. 次に, 式(7)に式(8)を代入すると,

$$
\tau_{\mathrm{L}}=k_{\mathrm{MGG}} h p \cos (\theta+S)
$$

となる．ここで，ばね定数 $k_{\mathrm{MGG}}$ を

$$
k_{\mathrm{MGG}}=R \frac{m g l}{p h}
$$

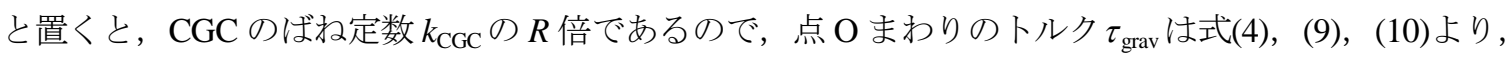

$$
\begin{aligned}
& \tau_{g r a v}=\tau_{\mathrm{L}}-\tau_{\mathrm{A}} \\
& =R m g l \cos (\theta+S)-m g l \cos \theta \\
& =m g l(R \cos (\theta+S)-\cos \theta)
\end{aligned}
$$

となる.この $\tau_{\text {grav }}$ が 0 の時，作動リンクは平衡姿勢となる.ここで， $m g l \neq 0$ なので，

$$
\begin{gathered}
0=R \cos (\theta+S)-\cos \theta \\
0=R \cos \theta \cos S-R \sin S \sin \theta-\cos \theta
\end{gathered}
$$

となる.まず, $\theta=0$ で作動リンクが平衡する場合の作動リンクパラメータ $(R, S)$ を求める. 式 $(12)$ に $\theta=0$ を代入 して，式(13)の関係となる.

$$
\begin{aligned}
& 0=R \cos S-1 \\
& S=\cos ^{-1}\left(\frac{1}{R}\right)
\end{aligned}
$$

次に, $\theta \neq 0$ の場合の作動リンクパラメータ $(R, S)$ を求める. 式(12)において両辺を $\sin \theta て ゙$ 除すると,

$$
\begin{gathered}
0=\frac{1}{\tan \theta} R \cos S-R \sin S-\frac{1}{\tan \theta} \\
(R \cos S-1) \frac{1}{\tan \theta}=R \sin S \\
\theta=\tan ^{-1}\left(\frac{R \cos S-1}{R \sin S}\right)
\end{gathered}
$$

のように平衡する角度と作動リンクパラメータ $(R, S)$ の関係が導出される.このように，作動リンクパラメータ を調整することで作動リンクを- $\pi / 2<\theta<\pi / 2$ の範囲の任意の姿勢に付勢できることが示された. なお，この時の $\theta$ を平衡姿勢 $D(-\pi / 2<D<\pi / 2)$ と改める. 


\section{4. 平衡姿勢の特性}

\section{$4 \cdot 1$ 運動方程式}

単リンクの MGG の動特性を検証する，比較のため，まず単振り子を垂直平面内で自由振動させた場合の運動 を考える. 運動方程式は, リンクの $\mathrm{O}$ 点まわりの慣性モーメントをI, クーロン摩擦を $\tau$, 振り子の角速度に比例 寸る粘性抵抗係数を $f$ とすると図 2 において,

$$
\begin{gathered}
I \ddot{\theta}=\tau-f \dot{\theta}-m g l \cos \theta \\
I \ddot{\theta}=\tau-f \dot{\theta}-m g l \sin \left(\theta+\frac{\pi}{2}\right)
\end{gathered}
$$

と記述できる.この式(15)では，重力により単振り子が鉛直下向きに付勢されて平衡することが分かる. 同時に, この鉛直下向きの姿勢の近傍で正弦を線形近似寸ることで，制御が簡単となり精度の向上が期待できる，一方， MGG の場合を考える. これは，基部傾斜角度 $S$ と自重補償倍率 $R$ の補償用ばねを備えた単振り子として扱える ので，式(11)を参考に，

$$
I \ddot{\theta}=\tau-f \dot{\theta}-m g l \cos \theta+m g l R \cos (\theta+S)
$$

と記述できる．この重力項(右辺第 2 項)を，正弦で合成すると，

$$
\begin{aligned}
& -m g l(\cos \theta-R \cos (\theta+S)) \\
& =-m g l((1-R \cos S) \cos \theta+R \sin S \sin \theta) \\
& =-m g l \sqrt{(1-R \cos S)^{2}+(R \sin S)^{2}} \sin (\theta-D)
\end{aligned}
$$

と記述できる。ただし，Dは，

$$
D=\tan ^{-1}\left(\frac{R \cos S-1}{R \sin S}\right)
$$

であり，平衡姿勢である．さらに，重力の大きさに対する仮想重力の大きさの倍率 $G$ を，

$$
G=\sqrt{(1-R \cos S)^{2}+(R \sin S)^{2}}
$$

と置けば，式(15)との比較により，式(17)は重力の方向が右回りに $D+\pi / 2$ 傾いて大きさが $G$ 倍された場合の単振 り子の振動と考えることができる。 この平衡姿勢 $D$ において, 倍率 $G$ で働く力を仮想重力 $(G, D)$ と定義する. 次節以降では，この仮想重力が任意に設定できるかを検証する.

\section{$4 \cdot 2$ 仮想重力の方向}

図 5 に基部傾斜角度 $S$ と平衡姿勢 $D$ の関係を自重補償倍率 $R$ ごとに示した. なお，図中や文中では，角度の関 係を理解しやすく寸るため, リンク角度 $\theta$, 基部傾斜角度 $S$ と平衡姿勢 $D$ を度数法で表記している場合がある. 図をみると，自重補償倍率 $R$ が 1 より十分大きい場合は，曲線の傾きは-1 となっている．これは，基部と作動リ ンクが一体となり傾斜している状態を表している. 次に, 自重補償倍率 $R$ が 1 より小さく十分 0 に近い場合は, 傾きが 0 となっている．これは，常に重力により鉛直下方に付勢された状態を表している．最後に，自重補償倍 率 $R$ が 1 の場合は傾きが-0.5 と近似でき, 基部傾斜角度の半分だけ水平よりも下方に傾斜して平衡していること が分かる．その他の範囲では，自重補償倍率 $R=1$ の平衡姿勢に， $R<1$ では下から， $R>1$ では上から漸近するよう なグラフとなることが分かる. 特に自重補償倍率が 1 より若干大きい場合(例 : $R=1.25$ )は，度数法表記で， $S$ が約 $0 \operatorname{deg}$ の場合に平衡姿勢 $D$ を約 $90 \mathrm{deg}, S$ が約 $5 \mathrm{deg}$ の場合 $D$ を約 $45 \mathrm{deg}, S$ が約 $15 \mathrm{deg}$ の場合 $D$ を約 $0 \mathrm{deg}, S$ が約 


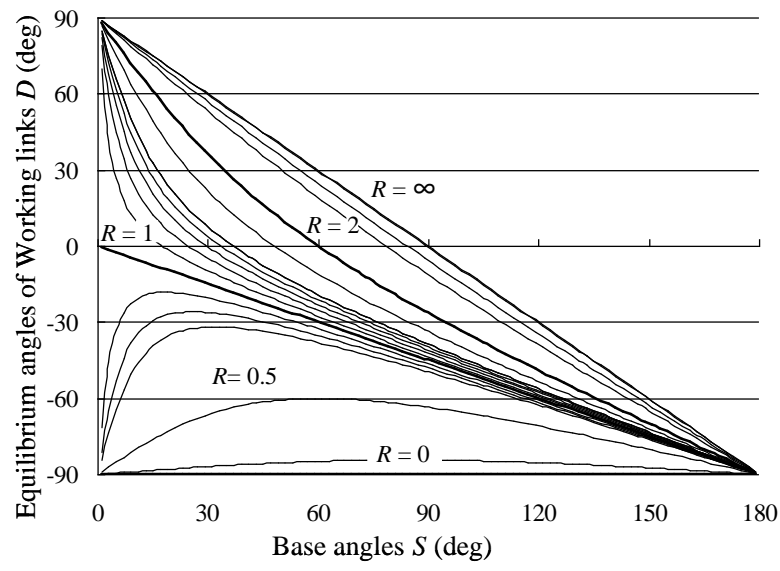

Fig. 5 Relationship between base angles and equilibrium angles of the link by comparison rates

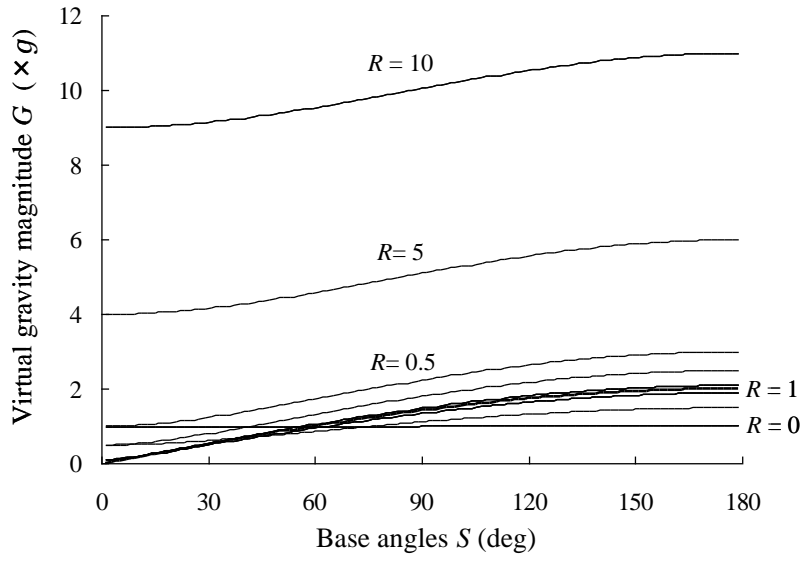

Fig. 6 Relationship between base angles and virtual gravity magnitude by comparison rates

30deg の場合 $D$ を約-10deg に設定できる．このように，基部の角度を少し調整するだけで平衡姿勢を第一象限か ら第四象限へと幅広く切り替えられることが分かる.

\section{$4 \cdot 3$ 仮想重力の大きさ}

仮想重力の倍率 $G$ と基部傾斜角度 $S$ の関係を自重補償倍率 $R$ ごとに図 6 に示した. 図のように, 自重補償倍率 $R$ によらず， $G$ が $S$ に対して単調増化することがわかる．また， $G$ の変化は $S$ が度数法表記で $35 \mathrm{deg}$ から $125 \mathrm{deg}$ の間でほぼ線形的になっている．そのため，この区間では式(19)を線形近似して $G$ と $S$ の関係を予測することも できる.

\section{5. 仮想重力の設定}

\section{$5 \cdot 1$ 自重補償倍率の設定}

MGG により各作動リンクに発生させる仮想重力 $(G, D)$ が，作動リンクパラメータ $(R, S)$ の調整により任意に 設定可能であるか確認する．はじめに，仮想重力の倍率 $G$ について確認する． $G$ は式(19)のように，自重補償倍 率 $R$ と基部角度 $S$ で設定できる. 両辺が正なので 2 乗して展開すると，

$$
\begin{gathered}
G^{2}=(1-R \cos S)^{2}+(R \sin S)^{2} \\
2 R \cos S=R^{2}-G^{2}+1
\end{gathered}
$$

となる. $R>0$ なので,

$$
\cos S=\frac{R^{2}-G^{2}+1}{2 R}
$$

と書き換えられる.ここで $S$ が $(0<S<\pi)$ 実数解を持つためには

$$
\begin{gathered}
-1<\frac{R^{2}-G^{2}+1}{2 R}<1 \\
-2 R<R^{2}-G^{2}+1<2 R
\end{gathered}
$$

の関係が成立するはずである. $-2 R<R^{2}-G^{2}+1$ を整理すると $R$ と $G(R, G>0)$ の関係は, 


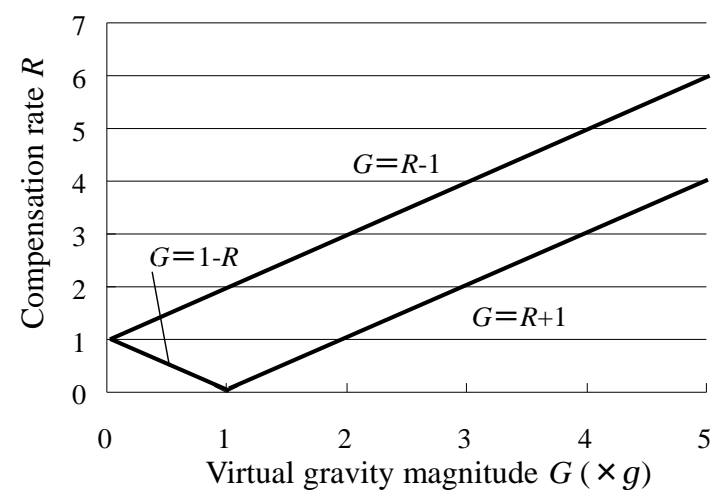

Fig.7 Combinations of virtual gravity magnitude and comparison rate for the presence of base angles

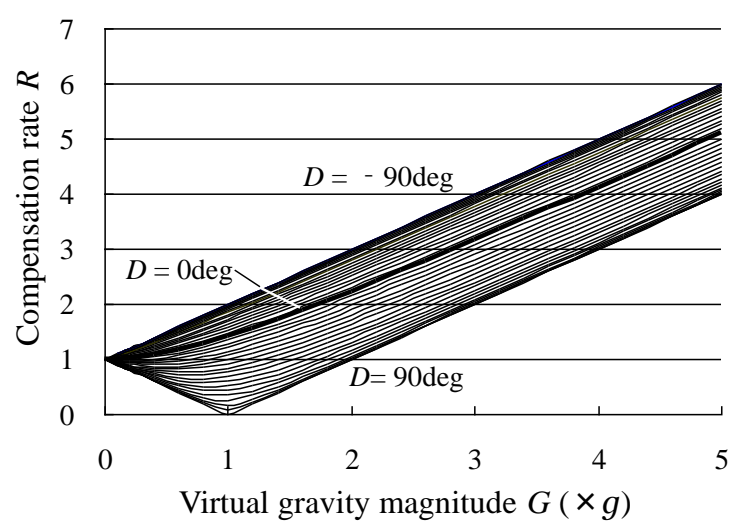

Fig. 8 Relationship virtual gravity magnitude and comparison rate by equilibrium angles

$$
\begin{aligned}
G^{2} & <(R+1)^{2} \\
0 & <G<R+1
\end{aligned}
$$

になる. 次に, $R^{2}-G^{2}+1<2 R$ を整理すると, $R$ と $G$ の関係は,

$$
\begin{gathered}
(R-1)^{2}<G^{2} \\
G>1-R(0<R \leq 1) \\
G>R-1 \quad(1<R)
\end{gathered}
$$

となる.この式(23)と式(24)により決まる $S$ が存在するための $R$ と $G$ の範囲は図 7 の実線の内側となる.

次に任意の仮想重力の平衡姿勢 $D$ を選択した場合に, $R$ と $G$ がどのような範囲をとるのか求める. この範囲と 先に求めた図 7 の範囲の重なる部分が，作動リンクパラメータ $(R, S)$ の調整で実現できる仮想重力 $(G, D)$ が一対一 に存在する範囲である。まず, 式(21)を式(18)に代入して $S$ を消去し整理すると,

$$
\begin{aligned}
& D=\tan ^{-1}\left(\frac{R\left(\frac{R^{2}-G^{2}+1}{2 R}\right)-1}{R \sqrt{1-\left(\frac{R^{2}-G^{2}+1}{2 R}\right)^{2}}}\right) \\
& \sqrt{R^{2}-\left(\frac{R^{2}-G^{2}+1}{2}\right)^{2}} \tan D=\frac{R^{2}-G^{2}-1}{2}
\end{aligned}
$$

となる.さらに，両辺を２乗すると以下の関係が得られる.

$$
\begin{aligned}
& \left(R^{2}-\left(\frac{R^{2}-G^{2}+1}{2}\right)^{2}\right) \tan ^{2} D \\
& =\frac{1}{4}\left(\left(R^{2}-G^{2}\right)^{2}-2\left(R^{2}-G^{2}\right)+1\right)
\end{aligned}
$$

続いて, 式(26)を $\left(R^{2}-G^{2}\right)$ に着目して整理する. 


$$
\left(R^{2}-\frac{1}{4}\left(\left(R^{2}-G^{2}\right)^{2}+2\left(R^{2}-G^{2}\right)+1\right)\right) \tan ^{2} D=\frac{1}{4}\left(\left(R^{2}-G^{2}\right)^{2}-2\left(R^{2}-G^{2}\right)+1\right)
$$

次に, $\left(1+\tan ^{2} D\right)$ をくくり出すと,

$$
-G^{2}=\frac{1}{4}\left(\left(R^{2}-G^{2}\right)^{2}+2\left(R^{2}-G^{2}\right)+1-4 R^{2}\right)\left(1+\tan ^{2} D\right)
$$

となり,これを $R^{2} の 2$ 次方程式として $R^{2}$ に関して整理すると，

$$
\left(R^{2}\right)^{2}-2\left(1+G^{2}\right) R^{2}+G^{4}-2\left(\frac{-1+\tan ^{2} D}{1+\tan ^{2} D}\right) G^{2}+1=0
$$

となる．解の公式より， $R^{2}$ は以下のように求められる.

$$
R^{2}=1+G^{2} \pm \sqrt{\left(1+G^{2}\right)^{2}-\left(G^{4}-2\left(\frac{-1+\tan ^{2} D}{1+\tan ^{2} D}\right) G^{2}+1\right)}
$$

これを，整理すると次のようになる.

$$
R^{2}=G^{2} \pm 2 G|\sin D|+1
$$

ここで $R$ は実数解をもつので, 式(31)の右辺を $G$ の 2 次方程式とみて, その判別式 $d$ が $d \leqq 0$ の関係でなくてはな らない。

$$
d=\sin ^{2} D-1 \leq 0
$$

式(32)より判別式 $d$ は $D$ がいかなる值をとっても $d \leqq 0$ であり, $R^{2}$ が正の数の解をもつことが分かる.ただし, 式(25)を 2 乗して式(26)として計算を行ったので, 条件を満たす解は 1 つである. 図 4 において作動リンクが平衡 する解を第 1 ,第 4 象限に持つのは,

$$
R=\sqrt{G^{2}+2 G \sin D+1}
$$

だけである.さらに，式(33)を用いて $D$ を設定するために必要な $R$ と $G$ の組み合わせを図 8 に示した．図 8 をみ ると, $R$ と $G$ がとる範囲が, 図 7 の範囲に完全に収まる(一致する)ことが分かる. よって, 自重補償倍率 $R$ は, 仮想重力の倍率 $G$ と方向 $D$ によって，任意に設定できることが確認された.

\section{$5 \cdot 2$ 基部傾斜角度の設定}

前節までに自重補償倍率 $R$ を $G$ と $D$ から導出する方法を示した．本節では，任意の仮想重力 $(G, D)$ を MGG の作動リンクパラメータ $(R, S)$ によって設定する方法を示す. そこで, 基部傾斜角度 $S$ を $G$ と $D$ から導出する式 を求める. 式(33)を式(14)に代入して，Rを消去する.

$$
S=\cos ^{-1}\left(\frac{\left(\sqrt{G^{2}+2 G \sin D+1}\right)^{2}-G^{2}+1}{2 \sqrt{G^{2}+2 G \sin D+1}}\right)
$$






Fig.9 Relationship base angles and equilibrium angles by virtual gravity magnitude



(a) $S=5 \mathrm{deg}$

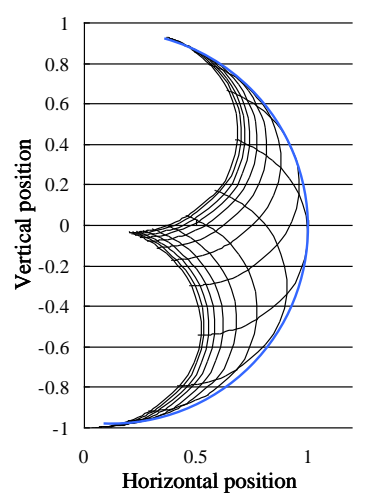

(b) $S=10 \mathrm{deg}$

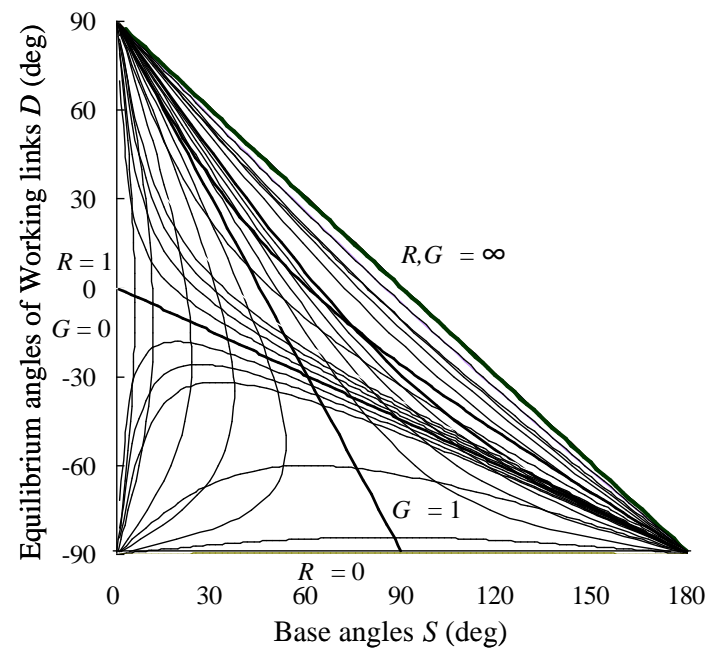

Fig.10 Transformation diagram of virtual gravity: Gravity delta

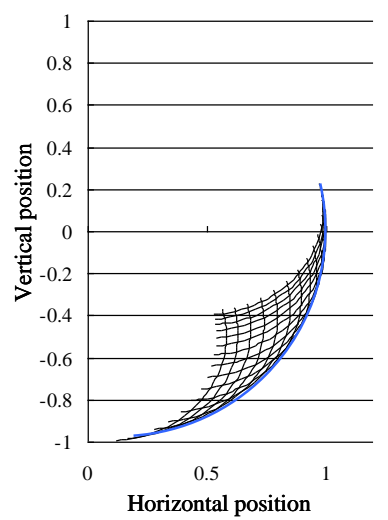

(c) $S=45 \mathrm{deg}$

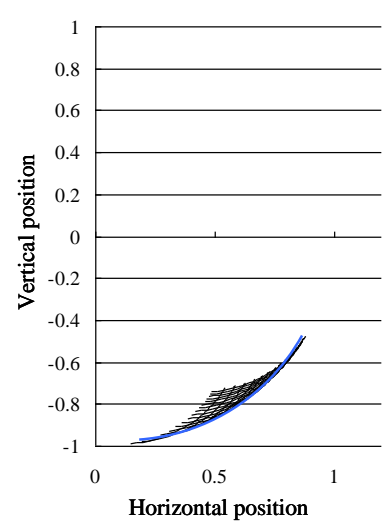

(d) $S=90 \mathrm{deg}$

Fig. 11 Work area of 2DOF link MGG by base angles

式(32)よりルートの中は常に正であるので,

$$
S=\cos ^{-1}\left(\frac{G \sin D+1}{\sqrt{G^{2}+2 G \sin D+1}}\right)
$$

となる.この式(35)を利用して， $G$ ごとの $S$ と $D$ の関係を図 9 に示した. 図からわかるように, $S$ は一組の $(G$, $D)$ から一義的に決定されることが分かる. また, 設定したい仮想重力の要求值 $(G, D)$ 㘦, それを実現する作動 リンクパラメータ $(R, S)$ を求めること, それとは逆に設計できる作動リンクパラメータ $(R, S)$ から実現できる仮 想重力 $(G, D)$ を求めることのできる早見図として図 10 を例として示寸.この図は，図 5 と図 9 を重㸚あわせた もので，設計できる $R$ と $S$ 範囲を事前に図示して，視覚的に比較することが可能である.

\section{$5 \cdot 3$ 多連結時の先端到達範囲}

前節までに, 単リンクの MGG の平衡姿勢を自由に設定できることを示した. 本節は, 複数リンクを直列に連 結した場合の作動リンクの平衡姿勢について検証する. 先に説明したように, MGG は平行リンク機構を用いる ことで, 姿勢変化に伴うモーメントの変化を他関節に伝達しない. そのため, 複数リンク接続した場合の平衡姿 勢の検証をする場合においても2 リンクの MGGについて考えれば予想が可能である. そのため, 図 3 に示した 


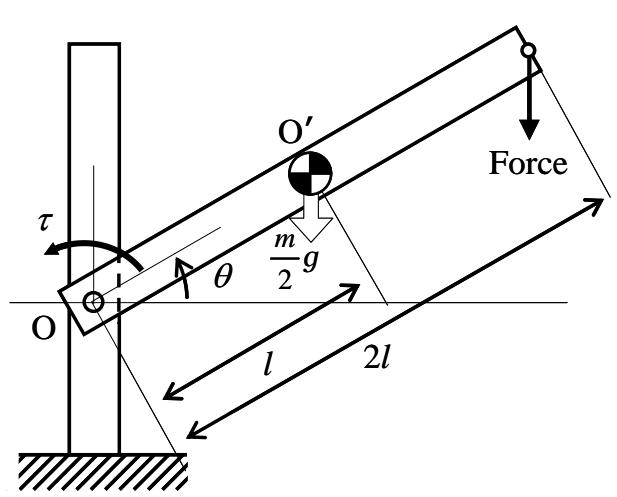

Fig.12 Model of link

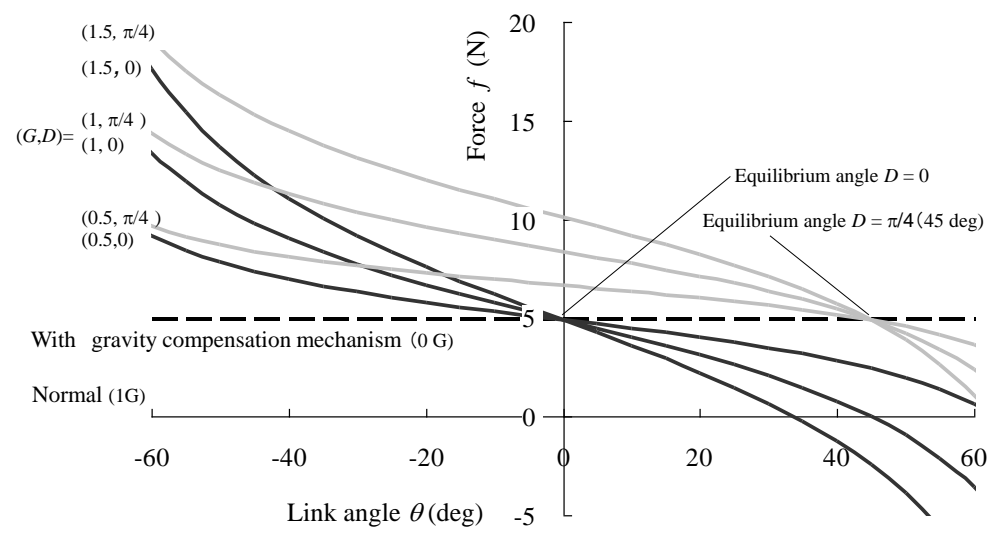

Fig.13 Output characteristic by each condition.

2 連結の MGG(作動リンク 1，2 の長さ=0.5)を検証対象とした. 図 3 の MGG は第 1 リンクと第 2 リンクの基部の 傾斜角度を同時に調整するように連結されているため, 基部傾斜角度 $S$ は作動リンクごとに独立に設定できない. 個別に設定する機構も実現可能であるが, 今回は原理の検証を目的としているため, より簡単な機構を採用した. この場合, 作動リンクの平衡姿勢は 3 つの作動リンクパラメータ $\left(R_{1}, R_{2}, S\right)$ で決まる. つまり, 3 つのパラメータ を設定することで，2つの作動リンク姿勢によって，第 2 リンクの先端位置が一義的に決まることになる. よっ て, $\left(R_{1}, R_{2}, S\right)$ と作動リンク 2 の先端が到達できる範囲を把握することで複数連結した場合の平衡姿勢変化の概 要を検証した. 図 11 は, 作動リンク 2 の先端の可動範囲を基部傾斜角度 $S$ ごとに表している. この図では, 各作 動リンクの自重補償倍率 $R_{1}, R_{2}$ を 0.1 から 2 まで 0.1 刻みに調整した. 図から分かるように, 基部傾斜角度 $S$ が 増加するにつれて先端位置の収束寸る範囲が狭まる。つまり $R$ を同じ刻み幅で調整しても， $S$ が大きい場合のほ うが，先端を高い位置精度で動か寸ことができることになる。これは，第 4 象限での作動に限定すれば，基部傾 斜角度 $S$ の調整によって先端の位置精度を調整していることを示している.

さらに，3 連結した場合は，同じ平面上の位置にどのような方向から作動リンクが到達するかも調整可能であ り, 4 連， 5 連と連結数を増すほどにその到達範囲と方向の組み合わせ数が増加する. このため, 基部傾斜角度を 調整すれば，2 連結の場合と同じく先端の到達範囲と方向についての位置精度を調整できる.

\section{6. 仮想重力機構による高出力化}

MGG は機械的な自重補償装置と同様に，作動リンクの高出力が期待できる．そこで本章では，任意の作動リ ンクに MGG を組み込んだ場合の, 作動リンク角度ごとの出力の変化を分析する. 今回は図 12 に示す単リンクを

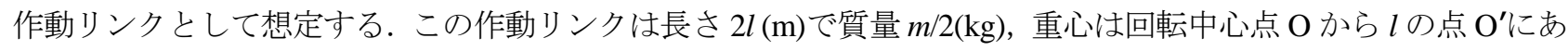
る. なお，静的なつり合い状態を見たいため，作動リンクの駆動軸に角度に依存しないトルク $\tau(=m g l)$ をかけ た場合に, 作動リンク角度 $\theta$ が $(-\pi / 3 \leqq \theta \leqq-\pi / 3)$ の範囲で先端リンクに懸架できる荷重 $f(\mathrm{~N})$ のきさで出力を表し た. MGG の構成する仮想重力 $(G, D)$ は， $(0.5 ， 0) ，(1,0),(1.5,0)$ および, $(0.5, \pi / 4),(1, \pi / 4),(1.5, \pi / 4)$ を代 表として検証した。また比較のため, (A)：作動リンクとアクチュエータのみ, (B) : 機械的な自重補償機構であ るCGCを組み込んだ場合, についても検証した。

(A) 作動リンク：駆動トルク $\tau=m g l$ と重力による自重トルクがかかるため,

$$
\begin{gathered}
f 2 l \cos \theta=m g l-\frac{m}{2} g l \cos \theta \\
f=\frac{m g(2-\cos \theta)}{4 \cos \theta}
\end{gathered}
$$


のように出力 $f(\mathrm{~N})$ が計算できる.

(B) 自重補償 : 自重トルクは相殺されており, 駆動トルク $\tau=m g l$ だけ考えればよいので,

$$
\begin{gathered}
f 2 l \cos \theta=m g l \\
f=\frac{m g}{2 \cos \theta}
\end{gathered}
$$

のように出力 $f(\mathrm{~N})$ が計算できる.

(C) MGG : 駆動トルク $\tau=m g l$ と仮想的な自重トルクがかかるため, 次のように出力 $f(\mathrm{~N})$ が計算できる.

$$
\begin{gathered}
f 2 l \cos \theta=m g l-\frac{m}{2} G g l \sin (\theta-D) \\
f=\frac{m g(2-G \sin (\theta-D))}{4 \cos \theta}
\end{gathered}
$$

これらの式を利用して各条件での出力を図 13 に示した。図中の破線は(B)の場合，太線は(C)の場合であり，灰 色が $D=\pi / 4(45 \mathrm{deg})$, 黒色が $D=0(45 \mathrm{deg})$ を表している. 図から分かるように，(C)の MGG を組み込んだ場合は， 平衡姿勢 $D$ までは自重補償を行った場合よりも出力が高くなっているが, 作動リンクが平衡姿勢 $D$ よりも上方に 傾斜すると, 自重補償よりも出力が低くなる. さらに作動リンク角度が増加し, 式(36)の右辺と式(38)の右辺が等 しくなったとき, (A)の場合と同様の出力となる.この時の角度は以下のように導出できる. 式(36)の右辺と式(38) の右辺が等しくなるので,

$$
m g l-\frac{m}{2} g l \cos \theta=m g l-\frac{m}{2} G g l \sin (\theta-D)
$$

の関係が成り立っている。これを $\theta$ こいて解けば,

$$
\begin{gathered}
\cos \theta-G(\sin \theta \cos D-\sin D \cos \theta)=0 \\
1-G(\tan \theta \cos D-\sin D)=0 \\
\theta=\tan ^{-1}\left(\frac{G \sin D+1}{G \cos D}\right)
\end{gathered}
$$

のように求められる.よって,

$$
-\frac{\pi}{2} \leq \theta \leq \tan ^{-1}\left(\frac{G \sin D+1}{G \cos D}\right)
$$

の作動リンク角度の範囲において, MGG を組みこんだ場合のほうが, (A)の作動リンクよりも出力が高くなるこ とが保障される. そのため MGG は平衡姿勢 $D$ 近くの範囲と, 平衡姿勢より下方の範囲において, 出力の向上も 両立できると言える. 


\section{7. 結 言}

本研究では垂直平面内で回動するリンク機構において，任意の作業方向に平衡姿勢を生成して，駆動系の省エ 市化と安定化を狙った仮想重力機構の提唱を試みた．機械的自重補償装置の基本原理に着目し，基部の傾きと重 心位置の微調整を行うことで，任意の方向に任意の大きさの付勢力でリンクを平衡できる MGG を考案した. こ の MGG が平面内のどのような角度においても，作動リンクの運動方程式内に正の仮想的な重力を生成できるこ と,幅広い範囲で自重の影響を軽減しつつ出力を高められることを確認した. 得られた成果は以下の通りである.

1. 機械的な自重補償装置の基部角度とばね定数を調整することで, 任意の方向に作動リンクが平衡することを 示した.

2. MGGにより生成される付勢力が，仮想的な重力項として取り扱えることを示した.

3. 基部傾斜角度と自重補償倍率の組み合わせと仮想重力の方向と大きさの関係が一対一対応であることを示 した.

4. 2 自由度の MGG において, 基部角度の増加に比例して作動リンク先端の位置精度が向上すること示した.

5. MGG を組み込むことで平衡姿勢より下方で出力が向上することを示した.

\section{文献}

(1) Hirose, S., Ishii, T. and Haishi, A., "Float Arm V: Hyper-Redundant Manipulator with Wire-Driven Weight Compensation Mechanism”, Proceedings IEEE International Robotics and Automation, ICRA 2003 in Taiwan, (2003), pp.368-373.

(2) Ulrich, N. and Kumar, V., "Passive Mechanical Gravity Compensation For Robot Manipulators", Proceedings IEEE International Conference on Robotics and Automation, (1991), pp. 1536-1541.

(3) Morita, T., "A novel mechanism design for gravity compensation in three dimensional space", Proceedings of 2003 IEEE/ASME International Conference on Advanced Intelligent Mechatoronics, Vol.1, (2003), pp. 163-168.

(4) Boudewijn M. Wisse, Wouter D. van Dorsser, Rogier Barents, and Just L. Herder, "Energy-Free Adjustment of Gravity Equilibrators Using the Virtual Spring Concept", Proceedings of the 2007 IEEE 10th International Conference on Rehabilitation Robotics, (2007), pp. 742-750.

(5) 山田泰之, 森田寿郎, “摇動スライダクランク機構を用いた機械的自重補償装置”, 日本機械学会論文集 C 編, Vol. 76, No.767 (2010), pp.149-155.

(6) 朝倉俊行, 李運生, “ニューラルネットワークによる 2 リンク空気圧マニピュレータの安定化制御(機械力学,計測,自 動制御)”，日本機械学会論文集 C 編, Vol. 70, No. 692 (2004), pp. 1093-1099.

（7）小池関也, 下嶋浩, “作業座標サーボによるマニピュレータの位置とカの制御：制御則の提案と安定性解析”, 日本 機械学会論文集 C 編, Vol.60, No. 575 (1994), pp. 2323-2330.

(8) Just L. Herder, Arend L. Schwab, "ON DYNAMICALLY EQUIVALENT FORCE SYSTEMS AND THEIR APPLICATION TO THE BALANCING OF A BROOM OR THE STABILITY OF A SHOE BOX”, Proceedings of DETC 2004, ( 2004), pp. DET C20 04-5 7188. 